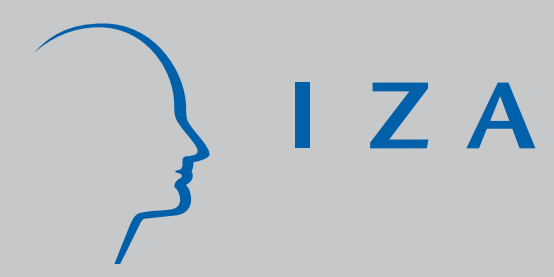

IZA DP No. 2419

The Part-Time Pay Penalty for Women in Britain

Alan Manning

Barbara Petrongolo

November 2006 


\title{
The Part-Time Pay Penalty for Women in Britain
}

\author{
Alan Manning \\ London School of Economics and CEP \\ Barbara Petrongolo \\ London School of Economics, CEP \\ and IZA Bonn
}

Discussion Paper No. 2419

November 2006

\author{
IZA \\ P.O. Box 7240 \\ 53072 Bonn \\ Germany \\ Phone: +49-228-3894-0 \\ Fax: +49-228-3894-180 \\ E-mail: iza@iza.org
}

\begin{abstract}
Any opinions expressed here are those of the author(s) and not those of the institute. Research disseminated by IZA may include views on policy, but the institute itself takes no institutional policy positions.

The Institute for the Study of Labor (IZA) in Bonn is a local and virtual international research center and a place of communication between science, politics and business. IZA is an independent nonprofit company supported by Deutsche Post World Net. The center is associated with the University of Bonn and offers a stimulating research environment through its research networks, research support, and visitors and doctoral programs. IZA engages in (i) original and internationally competitive research in all fields of labor economics, (ii) development of policy concepts, and (iii) dissemination of research results and concepts to the interested public.
\end{abstract}

IZA Discussion Papers often represent preliminary work and are circulated to encourage discussion. Citation of such a paper should account for its provisional character. A revised version may be available directly from the author. 
IZA Discussion Paper No. 2419

November 2006

\section{ABSTRACT}

\section{The Part-Time Pay Penalty for Women in Britain}

Women in Britain who work part-time have, on average, hourly earnings about $25 \%$ less than that of women working full-time. This gap has widened greatly over the past 30 years. This paper tries to explain this part-time pay penalty. It shows that a sizeable part of the penalty can be explained by the differing characteristics pf FT and PT women. Inclusion of standard demographics halves the estimate of the pay penalty. But inclusion of occupation makes the pay penalty very small, suggesting that almost the entire unexplained gap is due to occupational segregation. The rise in the pay penalty over time is partly a result of a rise in occupational segregation and partly the general rise in wage inequality. Policies to reduce the pay penalty have had little effect and it is likely that it will not change much unless better jobs can be made available on a part-time basis.

JEL Classification: J24, J31, J62

Keywords: part-time work, pay gaps, occupational segregation

Corresponding author:

Barbara Petrongolo

Department of Economics

London School of Economics

Houghton Street

WC2A 2AE

London

United Kingdom

E-mail: b.petrongolo@Ise.ac.uk 


\section{Introduction}

Something like $45 \%$ of female workers in Britain currently work part-time (PT) and the majority of British women will work part-time at some point in their lifetime.

Consequently, the types of jobs and the levels of pay and conditions that are available on a part-time basis are of crucial importance in influencing the economic opportunities of women. But, although the overall pay gap between men and women in the UK has fallen markedly (see, for example, Anderson et al, 2001) there has been an important difference in the fortunes of full-time (FT) and PT women over this period. While the earnings of FT women have been rising relative to men's this is not true of the earnings of PT women. Figure 1 presents a measure of the gap in average hourly earnings between FT and PT women using data from the New Earnings Survey (NES) for the period 1975-2001 and from the Labour Force Survey (LFS) for 1993-2003. The NES suggests that in 2001 the average hourly earnings among PT women were 26\% below those of FT women - for the LFS, the gap is somewhat lower though still substantial at $22 \%$. This pay gap is what we call the part-time pay penalty (PTPP) and its cause is the subject of this paper ${ }^{1}$. Furthermore, the NES suggests that the PTPP has risen over time (the PTPP was 15\% in 1975) though most of the rise in the PTPP seems to have occurred prior to 1995 and the LFS data does not suggest any very marked trend over the last 10 years.

The plan of the paper is as follows. In the next section we describe the data and compare the characteristics of FT and PT British women. Section 3 presents estimates of the current level of the PTPP in the UK. The main conclusion is that although the overall unadjusted PTPP is very large (as shown in Figure 1), this cannot be used a reliable estimate of the pay penalty that a given woman would suffer if she changed from FT to PT status because women working PT are very different from those working FT. If one takes account of these differences then the PTPP is $10 \%$ if one does not control for differences in occupation and 3\% if one does. That is, within occupations, the PTPP is very small. The true PTPP probably lies between these two numbers. Section 3 then considers trends in the UK PTPP, showing that the change over the last 30 years visible in Figure 1 can mostly be ascribed to rising differences in the types of jobs done by FT and PT women and to the general rise in UK wage inequality ${ }^{2}$. As occupational segregation of PT workers can explain most of the observed PTPP and part of its increase since 1975, Section 4 looks into the occupational mobility of PT and FT workers, and finds that moves to PT work tend to be

\footnotetext{
${ }^{1}$ It should be noted, although we do not analyse it, that there is also a large pay penalty for the $10 \%$ men who work part-time - the New Earnings Survey suggests that in 2003 part-time men had average hourly earnings that were $32 \%$ lower than the average hourly earnings of full-time men.

${ }^{2}$ This affects the PTPP because rising wage inequality has led to a wider wage gap between managers and cleaners, a change that tends to raise the PTPP because most managers work FT and most cleaners work PT.
} 
associated with downward occupational mobility. Section 5 then discussed possible causes for the observed patterns of job segregation and the resulting PTPP. Section 6 finally discusses policies that have been implemented or proposed in Britain with the aim of improving the conditions of PT workers and reducing the PTPP. Very few of the recent initiatives seem to have had much impact, largely because they have not been very effective in reducing the occupational segregation of FT and PT women.

\section{Data and Descriptive Statistics}

The main data set used in this paper is the LFS. This has two measure of part-time status, one based on self-assessment (the answer to the question "in your main job were you working full-time or part-time?”), and one based on basic usual weekly hours in the main job. In the UK the standard definition is that part-time workers have usual basic weekly hours less than or equal to 30 (with a cut-off of 25 for teachers as their hours reflect only classroom hours and not preparation/marking time) but, for example, a cut-off of 35 hours is more common in the United States (see, for example, Blank, 1990). One could spend considerable time debating the advantages and disadvantages of the subjective and objective measures but which is used does not seem to make much difference. Where possible we use the subjective measure as this most closely corresponds to the legal definition ${ }^{3}$ but we also report results using the objective measure.

Using the subjective measure Table A1 presents some descriptive statistics on FT and PT working women from the LFS. Women working PT are more likely than FT women to be less-educated, older, white, in a couple with dependent children who are both numerous and young, to be working in small establishments, in shops, hotels and restaurants, in a temporary job, with low job tenure and in low-level occupations. $28 \%$ of FT women are in professional or managerial occupations compared to $11 \%$ of PT women while 52\% of PT women are in personal service, sales or elementary occupations compared to $24 \%$ of FT women. Almost one in 4 PT women work as a care assistant, a shop assistant or a cleaner.

\section{The Current Level of the Part-Time Pay Penalty}

There is a small existing literature on the pay differential between FT and PT women. The earliest studies were for the US (e.g. Jones and Long, 1979; Blank, 1990) but there are also some studies for the UK. The first was probably Ermisch and Wright (1993) who used data

\footnotetext{
${ }^{3}$ For example, the 2000 Part-Time Workers' Regulations has the following definition “a worker is a part-time worker for the purpose of these Regulations if he is paid wholly or in part by reference to the time he works and, having regard to the custom and practice of the employer in relation to workers employed by the worker's employer under the same type of contract, is not identifiable as a full-time worker”
} 
from the 1980 Women and Employment Survey. In their data the average hourly earnings among PT women were approximately $85 \%$ of the average hourly earnings of FT women but much of this gap could be 'explained' by differences in education and work experience with an 'unexplained' PTPP in the region of 2-8\%. Harkness (2002, ch3) is the most thorough study for the UK - she uses data from the 1980 Women and Employment Survey, the British Household Panel Survey and the General Household Survey. She documents the rise in the PTPP from 1980 to 1998 and finds that much of this can be accounted for by changes in the characteristics of FT and PT women.

We start our analysis by a consideration of the current level of the PTPP. As shown in Figure 1 the raw gap in hourly pay between PT and FT women is large - PT women, on average earn 22\% less than FT women according to the 2003 LFS. But, it is not clear that this is a good measure of the pay penalty that would be suffered by an individual woman if she decided to switch from FT to PT status which is what we would like to be able to measure. For example, we have already noted that FT women are, on average, bettereducated than PT women so that part of the overall PT pay penalty can be accounted for by this education differential. As a switch from FT to PT status cannot be expected to be associated with a change in education we need to 'adjust' the overall pay penalty for this difference in education between FT and PT women. Similar considerations apply to other differences in characteristics between FT and PT women noted in the previous section.

However, the characteristics that should be controlled for in getting an estimate of the pay penalty that would be suffered by a woman who switches from FT to PT work is not entirely clear-cut. A particularly pertinent example is ‘occupation'. If a woman changes from FT to PT status a change in occupation may be necessary (see the evidence on this presented in Connolly and Gregory, 2006, and Manning and Petrongolo, 2004). If this is the case then an estimate of the PTPP that controls for occupation will not be capturing an important aspect of the PTPP and will only, at best, provide an estimate of the PTPP if a woman switches from FT to PT status without having to change occupation something that is perhaps over-optimistic. At the same time an estimate of the PTPP that does not control for differences in occupation may exaggerate the true PTPP as part of the reason that FT and PT women work in different occupations is the differences in labour market experience they possess. We deal with this problem by presenting estimates of the PTPP that both include and exclude occupation - it seems likely that the true PTPP lies somewhere between these two estimates.

Table 1 presents our estimates of the PTPP using data from the Labour Force Survey for 2001-2003 and using a variety of approaches. Our sample is women aged 16-64 inclusive who are not in full-time education. We exclude those whose reported hourly 
wages are below $£ 1$ per hour or above $£ 100$ per hour. The first row headed 'Unadjusted PTPP' shows that the average log hourly earnings of PT women are 25 log points less than the average log hourly earnings of FT women. But, as explained above this cannot be used as an estimate of the PTPP that would be suffered by a woman moving from FT to PT work because it does not control for differences in the characteristics of PT and FT women. The rest of the estimates in Table 1 do this though in different ways. The second row presents an estimate from an earnings function in which the dependent variable is the log hourly wage and a dummy variable for PT status is included together with controls for year, month, region, education, age, ethnicity, marital status, the number of children, the age of youngest child, job tenure, employer size and industry and, in the final two columns, occupation- we label this the Adjusted PTPP (Constant). The first column in the second row shows that when one controls for differences in characteristics between FT and PT women the PTPP falls from 25 to 12 log points. This halving of the PTPP occurs because PT women are less well-educated, they work in lower wage industries, they work in smaller workplaces and they are less likely to work in London (on the other hand, they are older which is associated with higher earnings). Although smaller than the unadjusted PTPP, this estimate is still quite large.

But, as the next two columns show the inclusion of occupation as additional controls makes a very large difference. In the second column we include the one-digit broad occupational categories and in the third column we include controls for the 370 3-digit occupations in the SOC 2000 classification. Inclusion of the broad occupational categories causes the adjusted PTPP to fall to $3.4 \log$ points and the inclusion of the narrow occupational categories causes it to fall to 2.5 log points. It is perhaps remarkable how much explanatory power is obtained just through the use of the 9 one-digit occupational categories. Although these estimates of the PTPP are significantly different from zero in a statistical sense they are rather small in absolute terms. The way to interpret this result is that, within occupations, the pay gap between PT and FT women is small. This is in line with evidence from other surveys e.g. Stevens et al (2004) finds that $74 \%$ of women say that their employer provides PT workers with the same hourly rate of pay.

The next two rows of Table 1 present estimates of the PTPP that allow it to vary with the characteristics of the woman by separate linear regressions for log hourly earnings for PT and FT workers and then applying Oaxaca decompositions. We report measures of the PTPP using the characteristics of the average PT worker and for the average FT worker. As can be seen the results are very similar both to each other and to the estimates based on the assumption that the PTPP is constant. 
The Oaxaca decomposition assumes that the mean of the log wage is linear in the covariates, a strong assumption. Hence we also report estimates based on a variant of the 're-weighting' method used by diNardo, Fortin and Lemieux (1996) that makes weaker assumptions. It involves estimating a probit model for whether a woman works FT and then re-weighting the observations of FT (resp. PT) women to ensure that the distribution of characteristics is the same as for PT (resp. FT) women. One can then compare the means to get an estimate of the PTPP for the average PT (resp. FT) woman. The estimates are reported in the $5^{\text {th }}$ and 6 th rows of Table 1.

The estimates of the PTPP presented so far are all based on the strong assumption that PT status is exogenous (conditional on the included covariates). However there are a number of reasons why PT status might be endogenous. First, individuals might differ in their commitment to the world of paid work and their ambitions in it. It seems plausible that those who are ambitious make greater investments in human capital that have a bigger payoff in FT work so that the PTPP is negatively correlated with whether individuals work PT. Secondly, there is the 'labour supply curve' argument. There is a very large literature that considers the impact of wages on hours of work. In contrast we have considered the impact of hours of work (specifically whether an individual is part-time or not) on wages. There is an obvious danger of reverse causation here: maybe it is low wages that 'cause' PT work, not PT work that 'causes' low wages. It should be noted that the existence of a PTPP might also cause problems for labour supply models (see Moffitt, 1984, and Lundberg, 1985, for studies that find evidence of a link between hours and hourly wages that is similar to a PTPP). Thirdly, if PT status is defined using an hours-based measure and hourly wages are computed by dividing a measure of weekly earnings by a measure of weekly hours (as is the case in both the LFS and the NES) then any measurement error in hours will result in a failure of exogeneity and a bias in the estimates of the PTPP.

To deal with potential sample selection biases we use standard Heckman sample selection correction techniques. For these techniques to work well requires a variable that affects the propensity to work PT but does not have a direct effect on earnings. Such a variable is difficult to find but to illustrate the difference the use of this methodology makes we will follow most of the papers in the literature (e.g. Ermisch and Wright, 1993; Blank, 1990) and assume that children and marital status affect the decision to work PT but not the wages earned. This is a very strong assumption that may not, in reality, be any better than the exogeneity assumption that this is supposed to replace. The 7 th and $8^{\text {th }}$ rows of Table 1 reports estimates of the PTPP that use this methodology ${ }^{4}$. They are very similar to those

\footnotetext{
${ }^{4}$ This robustness of the results to the estimation method is reassuring as, for example, using US data, Blank (1990) reports a very negative PTPP in the raw data, that becomes enormously negative when she uses
} 
using simpler approaches. The final row of Table 1 does a further robustness check and reports estimates of the PTPP using the hours-based definition of PT status - the results are very similar.

One other interesting question is the importance of different characteristics in accounting for the observed PTPP. Table 2 presents estimates using the approach where we allow the PTPP to vary by characteristics. In this approach one can evaluate the contribution of characteristics using either the returns to those characteristics for FT workers or PT workers. We report both in Table 2. The first row reports the unadjusted PTPP of 25 log points. The second row shows that differences in the characteristics of FT and PT workers (including occupation) can account for a gap of approximately 23 log points. By far the most important characteristic is occupation - this variable alone is responsible for approximately $70 \%$ of the accounted-for part of the PTPP. Education is the next most important followed by industry, employer size and region. Age works in the opposite direction: as PT workers are, on average, older than FT workers this factor tends to reduce the unadjusted PTPP.

We have shown that occupational segregation of PT women into low-paid occupations can explain a very large part of the unadjusted PTPP ${ }^{5}$. As a check on the conclusion that the PTPP is very small within occupation, Table 3 investigates differences across different occupation groups estimating the PTPP in a selection of very specific occupations in which there are large numbers of both FT and PT women. We report both the unadjusted PTPP and the adjusted PTPP assuming they are constant. In 5 of the 17 occupations reported in Table 3 there is a part-time pay premium and not a pay penalty although, once one includes controls a pay premium remains in only 3 of the 17 occupations and is only significantly different from zero in one of them (nursing auxiliaries and assistants $^{6}$ ). Among the other occupations the largest adjusted part-time pay penalty is 5.3\% among local government clerical assistants. The overriding impression from Table 3 is that, within occupations, the adjusted PTPP is small.

The unadjusted PTPP is very large with the average PT woman having hourly wages that are $22 \%$ below those of the average FT woman. But, because the average PT worker and FT worker are so different this unadjusted figure cannot be used as an estimate of the pay penalty that would be suffered by a woman switching from FT to PT work. An adjusted

\footnotetext{
instrumental variables as the estimation method and very positive when she uses a sample selectivity correction. At the end of the paper one is not sure quite what to think.

${ }^{5}$ It is worth noting that attempts to account for the pay gap between men and women are never as 'successful' as these results are in accounting for the PTPP. For example, the study of the UK gender pay gap by Anderson et al (2001) never managed to account for more than half of the unadjusted gap.

${ }^{6}$ This may be the result of the fact that many PT workers in this occupation are agency workers who are remunerated at a higher hourly rate than regular workers and should probably not be taken as a 'model' occupation for avoiding the PTPP.
} 
estimate of the PTPP that does not control for occupation is about $11 \%$. However this falls to $3.5 \%$ if occupation is controlled for. How one should interpret this importance of occupation is of vital importance. The fact that within occupations the gap in earnings between FT and PT workers is small suggests that women will not suffer a sizeable wage penalty if they can maintain their occupation while transferring from FT to PT status. But that is a big 'if': evidence in Petrongolo and Manning (2004) and Connolly and Gregory (2006) shows that many women do not maintain their current occupation while changing their working hours and are forced to make a downward occupational move if they want to move from FT to PT work. Evidence on the direction of occupational mobility of FT and PT workers will be presented in Section 5.

\section{Trends in the Part-Time Pay Penalty}

Figure 1 showed a dramatic growth in the PTPP from 14\% in 1975 to 28\% in 1995 after which there is not much of a noticeable trend - we would like to be able to understand this. This pre-dates the availability of LFS earnings data so here we use the New Earnings Survey (NES). With the NES one has to use an hours-based definition of PT status as there is no self-assessment question and many of the worker characteristics that are available in the LFS are not available in the NES - in the analysis that follows we use only age, industry and occupation.

Given that we have already shown that, for LFS data, one can explain a large part of the pay penalty using various characteristics, notably occupation, one might wonder whether this is true over time. Figure 2 plots the unadjusted PTPP and the adjusted PTPP once one controls for age, industry and occupation. What is most striking is that the adjusted PTPP shows very little change over time being around 10\% throughout the period 1975-2001. This estimate of the adjusted PTPP is larger than that found in the LFS, a result that can partly be explained by the fact that some important variables (education, employer size and household characteristics) are not present in the NES but would also seem to be partly the result of the fact that the estimated PTPP does seem larger in the NES than the LFS even when comparable definitions of PT status and the same control variables are used.

The implication of Figure 2 is that a growing part of the unadjusted PTPP can be accounted for by differences in age, industry and occupation between FT and PT women. The natural next question to ask is which of these variables are the most important. The answer is contained in Figure 3 - here we decompose the accounted-for part of the unadjusted PT pay penalty into the separate components due to differences in age, industry and occupation (using the coefficients from the FT wage equation). As was the conclusion for the analysis of the current pay penalty, occupation is far and away the most important of 
these three variables. Furthermore, the contribution of occupation has been rising over time - in 1975 occupation could account for 10 percentage points of the unadjusted pay penalty but by 2001 this had risen to almost 20 percentage points. Changes in the age distribution of FT and PT workers also contribute 5 percentage points to the rise. Industry is and always was relatively unimportant.

There are two possible explanations for why the contribution of occupational segregation to the PT pay penalty has risen through time. It could be that occupational segregation itself has risen so that the jobs done by FT and PT women are more different now than they were in the past. Or, it could be that the wage rewards attached to different occupations has changed in such a way that a given level of occupational segregation leads to a larger pay penalty now than in the past. In fact, we know that this is what has been happening in Britain over the past 25 years - there has been a big rise in wage inequality (see, for example, Machin, 2003) and a large part of this has been a rise in the earnings gap between those at the top e.g. managers and professionals and those at the bottom of the occupational pay ladder e.g cleaners and shop assistants.

One way of disentangling these two explanations is to keep the occupational pay structure constant at its value in a particular year and then just change the occupational distribution. This is done in Figure 4. The line labelled 'Current Year Coefficients' is the total contribution year-by-year of occupation to the overall pay penalty - this is the same as the line showing the contribution of occupation in Figure 3. Changes from year to year include both changes in the occupational segregation of FT and PT women and changes in the pay of different occupations. The line labelled '1975 Pay Structure' keeps the occupational pay differentials at their 1975 level so that changes year-on-year just represent changes in occupational segregation ${ }^{7}$. The PTPP would be about 5 percentage points lower in 2001 if we had kept the 1975 pay structure so that one half of the rise in the overall contribution of occupation to the PTPP is the result of changing occupational segregation and about half is the result of the changing occupational pay structure. As a check that this conclusion is not sensitive to the use of the 1975 pay structure we also show in the line labelled '2001 Pay Structure' what happens if we use the 2001 pay structure. The conclusions are very similar: the PTPP would have been 5 percentage points larger in 1975 if the occupational pay structure had been what it is today.

So, a substantial part of the increase in the PT pay penalty is a by-product of the changes in the UK labour market that have led to more wage inequality. These changes have occurred across the whole labour market, are not specific to women and not specific to parttime status. But they do have the effect of leading to a sizeable rise in the PT pay penalty.

\footnotetext{
${ }^{7}$ Note that, by construction the two lines must meet in 1975.
} 
There is a parallel here to the hypothesis of Blau and Kahn (2003) who argue that most of the variation in the total gender pay gap across countries can be ascribed to differences in the overall level of pay inequality and are not the result of gender-specific factors though they do have implications for pay differences by gender.

But the changes in the occupational distribution of PT and FT work do explain part of the rise in the pay penalty with an occupational up-grading of FT women over this period that is much greater than that occurring among PT women although even PT women are, on average, in higher-level occupations now than they were in 1975.

\section{Occupational segregation and occupational mobility of PT workers}

Our previous analysis showed that occupational segregation of PT workers can explain most of the observed PTPP and part of its increase since 1975. One of the key elements for our understanding of the PTPP is thus the occupational mobility of PT and FT workers.

Evidence on the direction of occupational moves can be gathered by assigning to each 3-digit occupation the average female wage in that occupation and then work out the change in the occupational wage associated with occupational moves. ${ }^{8}$ So if, for example, a woman moved from being a nurse (average wage $£ 10.06$ per hour) to being a care assistant (average wage $£ 5.41$ per hour) - and we do see some transitions like this in our data - this would be recorded as a $46 \%$ fall in the average occupational wage. While this approach is somewhat crude it does have the advantage of being able to summarize a large amount of information in a few numbers.

The results are reported in Table 4. In the first column we report results for all working women and in the second column for graduates as occupational down-grading may be more serious for them (as it is more likely they were initially in a well-paid job). First, let us consider the results for all women.

In the first row of Table 4 we regress the log of the occupational wage on controls for characteristics and a dummy for part-time status. The reported number shows that, PT women are in occupations which, controlling for other factors, pay $13.8 \%$ less than the occupations in which FT women find themselves. This estimate is in line with the overall contribution of occupation to the PTPP penalty that we reported above. The rest of Table 4 provides some evidence about the source of this occupational segregation.

All employment spells must start with an entry from non-employment and the second panel of Table 4 presents some information for those women entering employment from non-employment. The second row provides an estimate of the part-time occupational

\footnotetext{
${ }^{8}$ The use of occupational wages as a measure of occupation rakings avoids the hard tasks of summarizing all possible moves across 370 occupations, and to rank all the occupations on a one-dimensional scale.
} 
pay penalty for those entering employment that is $14.4 \%$, slightly above the overall PT occupational pay penalty. Although this estimate of the occupational PTPP is very large it is vulnerable to the criticism that FT and PT women entering employment have very different levels of labour market experience and this is partly a source of the observed PTPP. But, as the LFS contains information on previous occupation as long as the individual has worked within the last 8 years, we can look at occupational mobility across a spell of intervening non-employment - if a woman once had a particular job then it is not unreasonable to think she might be able to do it again. The third row of Table 4 presents an estimate of the occupational PTPP that is based on the change in the occupational wage. One can see that returning to work part-time means women suffer a wage penalty of $7.5 \%$ compared to those who return to work FT after controlling for previous occupation. This is lower than wage penalty reported in the previous row implying that those returning to work PT tend to have previously been in relatively low-paid occupations compared to those who are returning to work FT. But, the fact that there is still a sizeable pay penalty suggests that returning to work PT is associated with downward occupational mobility ${ }^{9}$. This is in line with other studies (Martin and Roberts, 1984; Joshi and Hinde, 1993; Blackwell, 2001; Houston and Marks, 2003) though, with the exception of Houston and Marks (2003) those other studies use data that is now quite old.

One might still argue that the estimate of the occupational PTPP in the third row of Table 4 does not control adequately for previous labour market experience. So, in the fourth row we restrict the sample to those who previously worked FT - the occupational PTPP is now higher at 9.9\%. One might further argue that this does not control for the length of time since the previous job was left (this might be important because skills might atrophy over time). So, in the fifth column we restrict the sample to women who previously worked FT less than 12 months ago so that the skills were very recently applied. The estimate implies that those returning to work PT suffer an occupational PTPP of 7.8\% suggesting that their skills are not being fully used. As a further check on this conclusion the sixth row of Table 4 uses a sample of those women whose were PT in their previous job. The estimate of $11.2 \%$ implies that those in this group who return to work FT do so in occupations that on average pay $11.2 \%$ more than the occupations of those who return PT.

But what happens within employment spells is also important so the third panel of Table 4 reports some estimates for those women who were in employment both currently and 3 months ago. In the seventh row the sample is those women who were in FT employment 3 months ago and the estimate implies that those women who are now working

\footnotetext{
${ }^{9}$ This estimate is conditional on those who report previous occupation that tends to be those who are returning to work after relatively short spells. But, as this group has a similar part-time pay penalty to those who do not have this information, the bias is likely to be rather small.
} 
PT suffer an occupational PTPP of 2\%. This includes women who both change employer and those who do not. The eighth row shows that among those women who were previously FT who have changed employer and have moved to PT status there is an occupational PTPP of $8.9 \%$ again suggesting that these women are no longer using all their skills. In contrast, for those women who change hours status without changing employer there is a very small pay penalty of $0.2 \%$. This suggests that one of the ways to avoid suffering a PTPP is to change hours status without changing jobs. The ninth, tenth and eleventh rows investigates the impact of moves from PT to FT status. The ninth row shows that those moving from PT to FT status get an occupational pay premium of $4.4 \%$. For those women who make the transition from PT to FT status without changing employer there is a pay premium of $2.1 \%$ while for those who change employer it is $8.1 \%$.

Finally, we might be interested in changes in occupation among women who do not change hours status and who do not change employer. As most of these moves are in an upward direction this can be thought of as a promotion. The twelfth row of Table 6.3 shows that PT workers are $0.1 \%$ less likely to change occupation than FT workers and the thirteenth row shows that, when they do change occupation the growth in occupational wages is $1.2 \%$ less for PT workers. This suggests that women are less likely to be on a career track within employers.

Table 4 has presented evidence that there is under-utilization of skills among PT workers. Perhaps the most telling pieces of evidence in this regard is that among women who move from FT to PT work with a change of employer there is an occupational pay penalty of $8.9 \%$ and for those who have worked FT in the past 12 months but who return to work PT there is an occupational pay penalty of $7.8 \%$.

If there is occupational down-grading and under-utilization of skills we might expect this to be more marked among highly-skilled workers for the simple reason that they have more to lose. Consequently, the second column of Table 4 repeats the same exercises for graduates. One sees the same patterns as for all women but what is very striking is that the occupational PTPP for graduates entering employment from non-employment are very large - of the order of $17 \%$ rather than the $8 \%$ found for all women. This does suggest a more acute problem with under-utilisation of skills among high-skill women.

\section{Possible explanations}

Reasons for the observed pattern of occupational segregation of PT workers and the resulting PTPP may reflect important elements of choice and constraint. First it may be that, for some reason, women choose to take a lower-level occupation when working PT even though the high-level job would be available on a PT basis. Or it may be that the constraint 
of working PT limits the distance women are prepared to travel to work because travel-towork is a fixed cost (and PT women do have lower commuting times than FT women) restricting the range of jobs available and resulting in under-utilization of skills (this argument could only work for women who work fewer hours per day rather than those who work fewer days per week). Or it could be that employers simply refuse to offer certain jobs on a PT basis. In turn there may be good reasons for this or it may be the result of prejudice?

A number of arguments have been put forward in the economics literature for why there may be a pay penalty attached to PT work. For example, Barzel (1973) argues that there are set-up costs in many jobs and productive work only starts once these set-up costs have been met. As PT workers then spend a lower proportion of their time at work on productive tasks, it is argued that their average hourly productivity and hence their wage will be lower. This argument would seem to apply best where there are daily set-up costs though this then limits the applicability of the argument to those PT workers who work fewer hours per day and not those who work fewer days per week. And, as we have seen that there are very small pay differences between PT and FT workers within occupations, this would also seem to suggest that this argument is not that important in practice.

One type of set-up costs is the fixed costs of hiring, training and administering workers. A PT worker probably costs as much as a FT worker to train or to hire or to administer, but the number of hours worked over which an employer can get a return on these costs is lower. As a result, employers will only be prepared to pay PT workers lower wages than FT workers or, if they are forced to pay similar wages, they will be more likely to employ FT workers in these types of jobs. Montgomery (1988) provides evidence for this effect. As high-level jobs typically require more training and are more costly to fill, this could explain the deficit of PT workers in high-level occupations. This view means that we would expect employers to look more favourably on existing workers who want to shift from FT to PT work (because the fixed costs of hiring and training have already been paid) than on hiring workers who want to be PT from the start.

All workers work with capital that costs money for the employer to provide and employers need to generate a return on capital equal to that available elsewhere in the economy. As capital is not being used in a productive way when workers are not at work, PT workers may not earn as much as FT workers if the utilization rate of the capital they work with is lower. Whether this is the case or not depends very much on the particular employer - capital can be shared among workers and, to the extent that it is, this will reduce the importance of this effect. And there are forces that go in the opposite direction. In many service occupations e.g. shops, restaurants, bars and personal services, productive work can 
only be done when customers are present. FT workers may be at work at times when there are very few customers reducing their productivity. If PT work can be targeted on peak times in customer demand one might expect hourly earnings to be higher among PT workers than FT workers.

Coordination costs also have potential to explain why PT workers may receive lower hourly wages than FT workers and why certain types of jobs may only be available on a FT basis. For example, a manager may have to give verbal instructions to workers on what to do - if there is one FT worker these instructions need only be given once while if there are two PT workers they may have to be given twice. And if the job of supervising some workers is split between two PT managers they may have to spend time communicating with each other about the problems they have had - this liaison will, again, cost money. And if groups of workers need to meet to discuss problems this is easier if all the workers are working FT because it may be easier to find a time when they are all in the office. Of course, there are often ways around these problems with a little imagination and it may be that inertia is as important an obstacle to making certain jobs available on a PT basis than any insurmountable problems to the organization of work posed by PT workers.

Which, if any, of these effects are important in practice? We do have some evidence on employer attitudes to PT working (and other flexible working practices) though this is an area where more research is needed. For example, the 2003 Employer Work-Life Balance Study (Woodland et al, 2004) provides a wide range of information on employer attitudes. They find that employers are generally supportive of the desire of workers to balance life and work primarily because they think this leads to a more contented and productive workforce. But there is evidence that employers do make it difficult for women to change from FT to PT work. For example, Woodland et al (2004) report that $60 \%$ of employers would expect to allow a woman returning from maternity leave to shift from FT to PT work and $65 \%$ of these would allow this with the woman retaining their previous job and seniority. These figures imply serious problems for women wanting to shift from FT to PT work when returning to work after maternity leave $-40 \%$ would be forced to change employer and another 20\% would be forced to accept a lower-status job. And Woodland et al (2004) show that employer attitudes towards women returning after maternity leave are the most favourable - for other women fewer employers reported being likely to be so accommodating. The reasons given by employers were almost exclusively related to business considerations.

Another study with relevant evidence on the attitudes of British employers to PT working is the case study research reported in Casey, Metcalf and Millward (1997). 24 employers in a range of sectors were interviewed about their attitudes to PT working as part 
of a wider investigation into their use of flexible labour. Their study makes it clear that employers do tend to label certain jobs as available or unavailable on a PT basis and conclude that "perceived advantages and disadvantages of a particular working-time practice are affected not only by objective facts but may also be affected by prejudice” (p119). Employers tended to see advantages in using part-time workers in tasks where workload varied over the course of a working day (e.g. in shops), where there was not enough work for a FT worker and in making their jobs more attractive to women. However, employers also saw disadvantages in fixed administrative costs, higher rates of labour turnover, lower flexibility in working hours and the need in professional and administrative jobs the need to hire more people and the costs of liaison among them. This last factor might be thought to be especially pertinent to the lack of PT managers.

We still do no understand all the reasons for the occupational segregation of PT women but it is important to make progress in this area if we are to seriously address the PTPP.

\section{Policy Options}

What can be done about the PT pay penalty? As our previous discussion has made clear the main cause of the pay gap between FT and PT women is the different types of jobs that these women do. And these differences seem to be the result of the fact that certain jobs do not seem to be available on a PT basis. It seems likely that any policy that fails to have an impact on this occupational segregation will fail to reduce the PTPP.

\section{Minimum Standards Policies}

Because women working PT tend to be in the jobs in the economy with the lowest level of wages any policy that reduces wage inequality will tend to improve the relative position of PT women even if that policy is not directly targeted on them. In the UK the most important recent initiative to reduce low pay has been the National Minimum Wage (NMW) introduced in April 1999. This was initially set at the rate of $£ 3.60$ per hour for adults and has been raised annually and is now (from October 2006) £5.35. Because PT women are more likely to be low-paid than FT women this has affected more PT workers than FT workers (Low Pay Commission, 2003, estimates that 53\% of the beneficiaries from the NMW are part-time women and only $17 \%$ are FT women). Hence we would expect the NMW to have reduced the PTPP.

Figure 5 shows the percentage growth in hourly wages at different percentiles (up to the third decile) in the wage distribution of PT and FT women for the period April 1998 to 
April 2000 that straddles the introduction of the NMW in April 199910. One can see that there was faster wage growth at the bottom end of the hourly wage distribution, something that is consistent with the impact of the NMW. One can also see that the impact of the NMW reaches further up the PT wage distribution (to about the 12th percentile) than the FT wage distribution (where it barely reaches the 5th percentile) and that the percentage wage increase at a given percentile is larger for PT women than for FT women. All of this is consistent with the NMW having a larger impact on the pay of PT than FT women.

However the actual impact of the introduction of the NMW on the PTPP implied by Figure 5 is small. One can get a measure of this impact by taking the difference between the two lines in Figure 6 - this adds up to about 1 percentage point11. This is consistent with Figure 1 where it is hard to see any dramatic change in the PTPP in 1999 when the NMW was introduced. This is because the NMW was set at a modest level. Other studies have found that the NMW has had a modest impact on overall wage inequality (Dickens and Manning, 2004) and on the gender pay gap (Robinson, 2002) and our finding here is in line with these studies. Unless the NMW is set at a considerably higher level it is not going to have a large effect on the PTPP.

Some other minimum standards policies may have had more effect, though not on pay. For example, the EU Working Time Directive that came into force in the UK in 1998 mandated a minimum of 4 weeks paid holiday a year (pro rata for PT workers who do not work 5 days a week). Prior to this there had been a substantial gap in the holiday entitlement of PT and FT workers and this has been markedly reduced since the directive came into force. Figure 6 shows a large reduction around this time in the percentage of PT women with no paid holiday.

\section{Equal Treatment Policies}

Another type of policy designed to reduce the gap between FT and PT workers are 'equal treatment policies' that require employers to treat PT and FT workers equally. In the UK the Part-time Workers Regulations that were introduced in 2000 aimed to ensure that "parttimers are not treated less favourably than comparable full-timers in their terms and conditions, unless it is objectively justified”

But, as the pay gap between FT and PT women in the same occupation seems to have been small even before 2000, ‘equal treatment' legislation is unlikely to have much impact on the PT pay penalty. Indeed the evidence on the evolution of the PTPP presented

\footnotetext{
${ }^{10}$ We do not use the NES for April 1999 as that data is exactly at the time of introduction of the NMW and almost certainly contains pay information relating to both before and after the introduction.

${ }^{11}$ This might be a slight under-estimate of the impact of the NMW on the PTPP as the NES is known to undersample low-paid part-time workers and we have not attempted to correct for this.
} 
in Figure 1 suggests this has been the case. And Figure 6 suggests these regulations have had little impact on the difference in holiday entitlement between PT and FT women even though the Working Time Directive had a large effect. It seems that there are relatively small differences in treatment of PT and FT workers within jobs currently in the UK and the problem is that the jobs done by PT and FT women are very different.

\section{Rights to Flexible Working}

One of the main problems facing women who want to work PT is that the better jobs do not seem to be available on a PT basis and that women making the transition from FT to PT work often have to change jobs to do so and suffer a downward occupational move. Given that the desire to work PT is often associated with the desire to spend more time with children this forces many women to choose between career and family. There have been some policy initiatives designed to strengthen the control of parents over their working hours. From 6 April 2003, parents of children aged under six or disabled children aged under 18 have the right to apply to work flexibly and their employers have a duty to consider these requests seriously. Flexible working is wider than just a change in the number of hours as it often involves a rearrangement of hours but it is certainly meant to include some change of hours status and evidence (e.g. Palmer, 2004) suggests that the desire to change from FT to PT work is the most common type of request. Some evidence suggests a large take-up by eligible women of these new rights. For example, DTI (2004) reports that $40 \%$ of parents had made a request, $60 \%$ had had them agreed and $63 \%$ of employers had had at least one request. It did report that women in senior positions were more likely to have their requests refused. However, as the report itself admits, the sample on which this report is based is highly selective. And Palmer (2004) reports, using data from the first DTI flexible working employee survey (that has a more representative sample), that $16 \%$ of women had made a request to work flexibly since April 2003 and 86\% of these requests had been fully or partly accepted by employers. It also reports a significant increase in the number of requests being approved.

Given this it is of interest to look at other data sets to see whether there is any evidence of change and this is possible as the LFS has, since 2001, contained information on various forms of flexible working. As the changes affect women with children aged less than 6 we distinguish this group from other women (who can be thought of as forming a control group). The legislation also affects women with disabled children of all ages but the numbers of these is relatively small and we have no way in our data to identify disabled children. Figures $7 \mathrm{a}$ and $7 \mathrm{~b}$ present evidence on the incidence of the most common forms of 
flexible working - there is little evidence of marked change after the introduction of the new regulations.

There are a number of possible interpretations of why the LFS data shows virtually no impact of the legislation when other surveys show a more dramatic impact. It could be that the true impact occurs prior to our earliest data in 2001 as employers changed practice in advance of the new rights coming into force, that few women have yet taken advantage of their new rights, that employers are finding ways of turning down requests, that these new rights are not perceived of being of value to many women, that women may be afraid to ask their employer for changes to their working hours or think it pointless if they know the request is going to be turned down. Intriguingly, Woodland et al (2003, p116) report that "the characteristics of the workplaces that has received such a request [to move from FT to PT work] match those of the workplaces that reported such requests were acceptable”. The evidence of limited impact does suggest that more monitoring is needed to ensure that the legislation is having its intended effect of giving employees more control over their working patterns.

\section{Conclusions}

On average women working PT in the UK have hourly earnings that are $22 \%$ less than women working FT - this is the PTPP. The PTPP has widened over the past 30 years with most of the deterioration occurring prior to the mid-1990s. But this cannot be used as an estimate of the pay penalty that would be suffered by a woman switching from FT to PT work as women working PT and women working PT are very different in their characteristics and do very different jobs. Taking account of these differences the part-time penalty for identical women doing the same job is estimated to be about $10 \%$ if one does not control for occupation and about 3\% if one does. Hence, it is the difference in the occupations of PT and FT women that can explain most of the pay differentials between them. The importance of occupation has increased over time as PT women have failed to make the occupational up-grades seen for FT women over the past 30 years. It is also the case that rising UK wage inequality has also acted to widen the pay gap between PT and FT women. There does seem to be a problem in the fact that women who want to move from FT to PT work are often forced to change employer and/or occupation and, on average, make a downward occupational move. This seems to occur even when they have the necessary skills and experience to do the higher-level job. The consequence is that there are many women working PT who do not seem to be making full use of the skills that they have.

Policy initiatives in recent years like the National Minimum Wage (1999), the PartTime Workers Regulations (2000) and the Right to Request Flexible Working (2003) appear 
to have made little difference to the part-time pay penalty. The most likely explanation of this is that, with the exception of the right to request flexible working, none of these policies are targeted on the routes by which PT women end up in low-level occupations. And the right to request flexible working is quite weak in that it allows employers many legitimate reasons for refusing requests. But it seems likely that more moves in this direction are likely to be the most effective way to breaking down barriers to the availability of high-level jobs on a PT basis that is the most likely way to reduce the PTPP. 
Table 1

Estimates of the PT Pay Penalty: Different Methodologies

\begin{tabular}{|c|c|c|c|}
\hline & $\begin{array}{c}\text { Basic } \\
\text { Controls }\end{array}$ & $\begin{array}{c}\text { Basic } \\
\text { Controls+ } \\
\text { broad } \\
\text { occupation }\end{array}$ & $\begin{array}{c}\text { Basic } \\
\text { Controls+ } \\
\text { narrow } \\
\text { occupation }\end{array}$ \\
\hline Unadjusted PTPP & -0.250 & -0.250 & -0.250 \\
\hline Adjusted PTPP (Constant) & -0.116 & -0.034 & -0.025 \\
\hline \multicolumn{4}{|c|}{ Oaxaca Decompostions } \\
\hline $\begin{array}{l}\text { Adjusted PTPP (Varying) } \\
\text { Average FT Woman }\end{array}$ & -0.114 & -0.032 & -0.024 \\
\hline $\begin{array}{l}\text { Adjusted PTPP (Varying) } \\
\text { Average PT Woman }\end{array}$ & -0.117 & -0.035 & -0.030 \\
\hline \multicolumn{4}{|c|}{ Reweighting Estimates } \\
\hline $\begin{array}{l}\text { Adjusted PTPP (Varying) } \\
\text { Average FT Woman }\end{array}$ & -0.069 & 0.000 & 0.011 \\
\hline $\begin{array}{l}\text { Adjusted PTPP (Varying) } \\
\text { Average PT Woman }\end{array}$ & -0.137 & -0.044 & -0.047 \\
\hline \multicolumn{4}{|c|}{ Sample Selection Correction } \\
\hline $\begin{array}{l}\text { Adjusted PTPP } \\
\text { (Av FT Woman) }\end{array}$ & -0.106 & -0.020 & \\
\hline $\begin{array}{l}\text { Adjusted PTPP } \\
\text { (Av PT Woman) }\end{array}$ & -0.145 & -0.051 & \\
\hline $\begin{array}{l}\text { Contribution of Sample } \\
\text { Selection Correction }\end{array}$ & 0.008 & -0.001 & \\
\hline \multicolumn{4}{|c|}{ Hours-Based Measure } \\
\hline Unadjusted PTPP & -0.268 & -0.268 & -0.268 \\
\hline Adjusted PTPP (Constant) & -0.119 & -0.027 & -0.036 \\
\hline $\begin{array}{l}\text { Adjusted PTPP (Varying) } \\
\text { (Average PT Woman) }\end{array}$ & -0.121 & -0.030 & -0.027 \\
\hline $\begin{array}{l}\text { Adjusted PTPP (Varying) } \\
\text { (Average FT Woman) }\end{array}$ & -0.117 & -0.0473 & -0.027 \\
\hline
\end{tabular}

Data is from Labour Force Survey, 2001-2003. Basic controls are for year, month, region, education, experience (age), ethnicity, marital status, the number of children, the age of youngest child, job tenure, employer size and industry. For the sample selection correction marital status and child variables are excluded from the basic controls and the sample selection equation also includes marital status and children. 
Table 2

The Importance of Different Factors in Accounting for the PT Pay Penalty

\begin{tabular}{lcc}
\hline & $\begin{array}{c}\text { FT Coefficients } \\
\text { Log points }\end{array}$ & $\begin{array}{c}\text { PT Coefficients } \\
\text { Log Points }\end{array}$ \\
\hline Unadjusted PTPP & -0.250 & -0.250 \\
PTPP Accounted for by & -0.226 & -0.219 \\
Characteristics & Of which the contribution of the following variables is (\%): \\
$\quad$ & 0.0 & 0.0 \\
Year/Month & 4.9 & 4.5 \\
Region & 16.4 & 11.8 \\
Education & -8.8 & -3.6 \\
Age & -0.4 & 0.0 \\
Race & 3.1 & -0.9 \\
Marital Status/ Children & 1.8 & 1.8 \\
Job Tenure & 5.3 & 3.6 \\
Employer Size & 9.3 & 13.2 \\
Industry & 68.1 & 70.0 \\
Occupation (Narrowly defined) & &
\end{tabular}

Note: The estimates come from the Oaxaca decompositions of Table 1.

Table 3

Part-Time Pay Penalties in selected Occupations

\begin{tabular}{lccc}
\hline & $\begin{array}{c}\text { Unadjusted } \\
\text { PTPP }\end{array}$ & $\begin{array}{c}\text { Adjusted } \\
\text { PTPP } \\
\text { (Constant) }\end{array}$ & $\begin{array}{c}\text { Number of } \\
\text { observations }\end{array}$ \\
\hline Primary \& nursery education teaching profs & $-1.4 \%$ & $-0.5 \%$ & 2359 \\
Nurses & $+4.3 \% *$ & $-0.4 \%$ & 3394 \\
Civil service admin officers and assistants & $+9.9 \%^{*}$ & $+3.3 \%$ & 1219 \\
Local government clerical officers \& assistants & $-5.2 \% *$ & $-5.3 \% *$ & 1257 \\
Accounts wages clerk, bookkeeper & $-3.9 \%^{*}$ & $-4.6 \%^{*}$ & 3107 \\
Counter clerks & $-4.9 \%^{*}$ & $-4.7 \% *$ & 1308 \\
Filing \& other records assistants \& clerks & $-5.5 \%^{*}$ & $-3.8 \%$ & 917 \\
General office assistants or clerk & $0.0 \%$ & $-3.2 \% *$ & 3529 \\
Personal assistants \& other secretaries & $-11.4 \% *$ & $-4.8 \% *$ & 2644 \\
Receptionists & $-1.6 \%$ & $-1.7 \%$ & 1792 \\
Nursing auxiliaries and assistants & $+7.0 \% *$ & $+7.1 \% *$ & 1427 \\
Care assistants and home carers & $+2.7 \% *$ & $+1.8 \%$ & 3575 \\
Educational assistants & $-6.2 \% *$ & $-2.9 \%$ & 2222 \\
Sales and retail assistants & $-3.5 \% *$ & $-1.5 \%$ & 5323 \\
Customer care occupations & $-5.4 \% *$ & $-4.0 \% *$ & 1410 \\
Kitchen and catering assistants & $-2.7 \%$ & $-2.5 \%$ & 1937 \\
Cleaners, domestics & $+0.2 \%$ & $0.0 \%$ & 3388 \\
\hline
\end{tabular}

Note: Other controls included are year, month, region, education, experience (age), ethnicity, marital status, the number of children, the age of youngest child, job tenure, employer size and industry. * Co-efficient is significantly different from zero at the $10 \%$ level 
Table 4

Occupational Mobility

\begin{tabular}{|c|c|c|c|c|}
\hline & Dependent Variable & Sample & All Women & Graduates \\
\hline 1 & Occupational wage & All Currently in Work & $-13.8 \%$ & $-13.1 \%$ \\
\hline \multicolumn{5}{|c|}{ Entrants from Non-Employment } \\
\hline 2 & Occupational wage & All Entrants & $-14.4 \%$ & $-14.6 \%$ \\
\hline 3 & Occupational wage & All Entrants & & \\
\hline & change & & $-7.5 \%$ & $-17.1 \%$ \\
\hline 4 & Occupational wage & Entrants who were previously & & \\
\hline & change & FT & $-9.9 \%$ & $-20.7 \%$ \\
\hline 5 & $\begin{array}{l}\text { Occupational wage } \\
\text { change }\end{array}$ & $\begin{array}{c}\text { Entrants previously FT }<12 \\
\text { months ago }\end{array}$ & $-7.8 \%$ & $-17.6 \%$ \\
\hline 6 & $\begin{array}{l}\text { Occupational wage } \\
\text { change }\end{array}$ & $\begin{array}{c}\text { Entrants who were previously } \\
\text { PT } \\
\text { Those Employed FT } 3 \text { Months Ago }\end{array}$ & $-11.2 \%$ & $-18.1 \%$ \\
\hline 7 & $\begin{array}{l}\text { Occupational wage } \\
\text { change }\end{array}$ & Previously in FT employment & $-2.0 \%$ & $-1.9 \%$ \\
\hline 8 & $\begin{array}{l}\text { Occupational wage } \\
\text { change }\end{array}$ & $\begin{array}{l}\text { Previously in FT employment } \\
\text { with change in employer }\end{array}$ & $-8.9 \%$ & $-9.3 \%$ \\
\hline 9 & $\begin{array}{l}\text { Occupational wage } \\
\text { change }\end{array}$ & $\begin{array}{c}\text { Previously in FT employment } \\
\text { with no change in employer } \\
\text { Those Employed PT } 3 \text { Months Ago }\end{array}$ & $-0.8 \%$ & $-0.9 \%$ \\
\hline 10 & $\begin{array}{l}\text { Occupational wage } \\
\text { change }\end{array}$ & Previously in PT employment & $-4.4 \%$ & $-5.5 \%$ \\
\hline 11 & $\begin{array}{l}\text { Occupational wage } \\
\text { change }\end{array}$ & $\begin{array}{l}\text { Previously in PT employment } \\
\text { with change in employer }\end{array}$ & $-8.1 \%$ & $-11.0 \%$ \\
\hline 12 & $\begin{array}{l}\text { Occupational wage } \\
\text { change }\end{array}$ & $\begin{array}{c}\text { Previously in PT employment } \\
\text { with no change in employer }\end{array}$ & $-2.1 \%$ & $-2.4 \%$ \\
\hline \multicolumn{5}{|c|}{ Those with no change in employer and no change in hours status } \\
\hline 13 & Change in Occupation & All Stayers & $-0.1 \%$ & $0.0 \%$ \\
\hline 14 & $\begin{array}{l}\text { Occupational wage } \\
\text { change }\end{array}$ & $\begin{array}{l}\text { Stayers with change in } \\
\text { occupation }\end{array}$ & $-1.2 \%$ & $-0.3 \%$ \\
\hline
\end{tabular}

Notes:

1. $\quad$ Data come from LFS for period June 2001 to February 2004.

2. Changes are from one quarter to another.

3. Other controls included are education, region, year, household characteristics, quartic in potential experience. 
Table A1

Descriptive Statistics

\begin{tabular}{|c|c|c|c|}
\hline Variable & $\begin{array}{l}\text { All Working } \\
\text { Women } \\
\%\end{array}$ & $\begin{array}{l}\text { FT Working } \\
\text { Women } \\
\%\end{array}$ & $\begin{array}{l}\text { PT Working } \\
\text { Women } \\
\%\end{array}$ \\
\hline Part-Time Working & 41 & 0 & 100 \\
\hline Graduates & 30 & 36 & 22 \\
\hline GCSE or equivalent & 34 & 31 & 39 \\
\hline No qualifications & 18 & 14 & 23 \\
\hline Age 16-19 & 3 & 3 & 2 \\
\hline Age $20-24$ & 8 & 11 & 4 \\
\hline Age 25-29 & 10 & 13 & 6 \\
\hline Age 30-34 & 13 & 13 & 12 \\
\hline Age 40-44 & 14 & 13 & 16 \\
\hline Age 45-49 & 13 & 13 & 13 \\
\hline Age 50-54 & 11 & 11 & 12 \\
\hline Age 55-59 & 10 & 8 & 12 \\
\hline Age 60-64 & 3 & 2 & 6 \\
\hline Married without Children & 47 & 54 & 36 \\
\hline Married with Children & 32 & 21 & 46 \\
\hline Single with Children & 10 & 8 & 12 \\
\hline Average Age of Youngest Child & 7.8yrs & $8.5 y r s$ & $7.2 \mathrm{yrs}$ \\
\hline Number of Children & 70 & 46 & 104 \\
\hline Black & 2 & 2 & 1 \\
\hline Asian & 3 & 3 & 2 \\
\hline Tyne \& Wear & 2 & 2 & 3 \\
\hline Rest of Northern Region & 3 & 3 & 2 \\
\hline South Yorkshire & 2 & 2 & 4 \\
\hline West Yorkshire & 4 & 4 & 3 \\
\hline Rest of Yorks \& Humberside & 3 & 3 & 7 \\
\hline East Midlands & 7 & 7 & 4 \\
\hline East Anglia & 4 & 4 & 5 \\
\hline Inner London & 3 & 4 & 2 \\
\hline Outer London & 6 & 7 & 5 \\
\hline South West & 9 & 8 & 9 \\
\hline West Midlands (met county) & 4 & 4 & 4 \\
\hline Rest of West Midlands & 5 & 5 & 5 \\
\hline Greater Manchester & 4 & 4 & 3 \\
\hline Merseyside & 2 & 2 & 2 \\
\hline Rest of North-West & 4 & 4 & 4 \\
\hline Wales & 5 & 5 & 5 \\
\hline Strathclyde & 4 & 4 & 3 \\
\hline Rest of Scotland & 6 & 6 & 6 \\
\hline Northern Ireland & 4 & 4 & 3 \\
\hline Job Tenure $<5$ years & 51 & 51 & 51 \\
\hline Job Tenure $10-15$ years & 12 & 12 & 12 \\
\hline Job Tenure $15+$ years & 16 & 17 & 16 \\
\hline Public Sector & 38 & 37 & 38 \\
\hline Non-permanent Job & 6 & 4 & 8 \\
\hline Establishment with >25 Employees & 64 & 70 & 55 \\
\hline Agriculture \& fishing & 0 & 0 & 0 \\
\hline Energy \& water & 0 & 1 & 0 \\
\hline Manufacturing & 8 & 11 & 5 \\
\hline Construction & 2 & 2 & 1 \\
\hline Transport \& Communication & 4 & 4 & 3 \\
\hline Banking, finance \& insurance etc & 14 & 17 & 11 \\
\hline
\end{tabular}




\begin{tabular}{|c|c|c|c|}
\hline Public admin, education \& health & 45 & 44 & 47 \\
\hline Other services & 5 & 5 & 6 \\
\hline Managers and senior officials & 10 & 14 & 4 \\
\hline Professional occupations & 11 & 14 & 7 \\
\hline Associate professional and technical & 14 & 17 & 11 \\
\hline Skilled trades occupations & 2 & 2 & 2 \\
\hline Personal service occupations & 14 & 12 & 17 \\
\hline $\begin{array}{l}\text { Sales and customer service } \\
\text { occupations }\end{array}$ & 11 & 7 & 17 \\
\hline $\begin{array}{l}\text { Process, plant and machine } \\
\text { operatives }\end{array}$ & 3 & 3 & 2 \\
\hline Elementary occupations & 11 & 5 & 18 \\
\hline
\end{tabular}

Note: Total sample size is 95,314

Source: Labour Force Survey March 2003-February 2004. Basic sample is women aged 16-64 who are not in full-time education.

Figure 1

The Part-time Pay Penalty

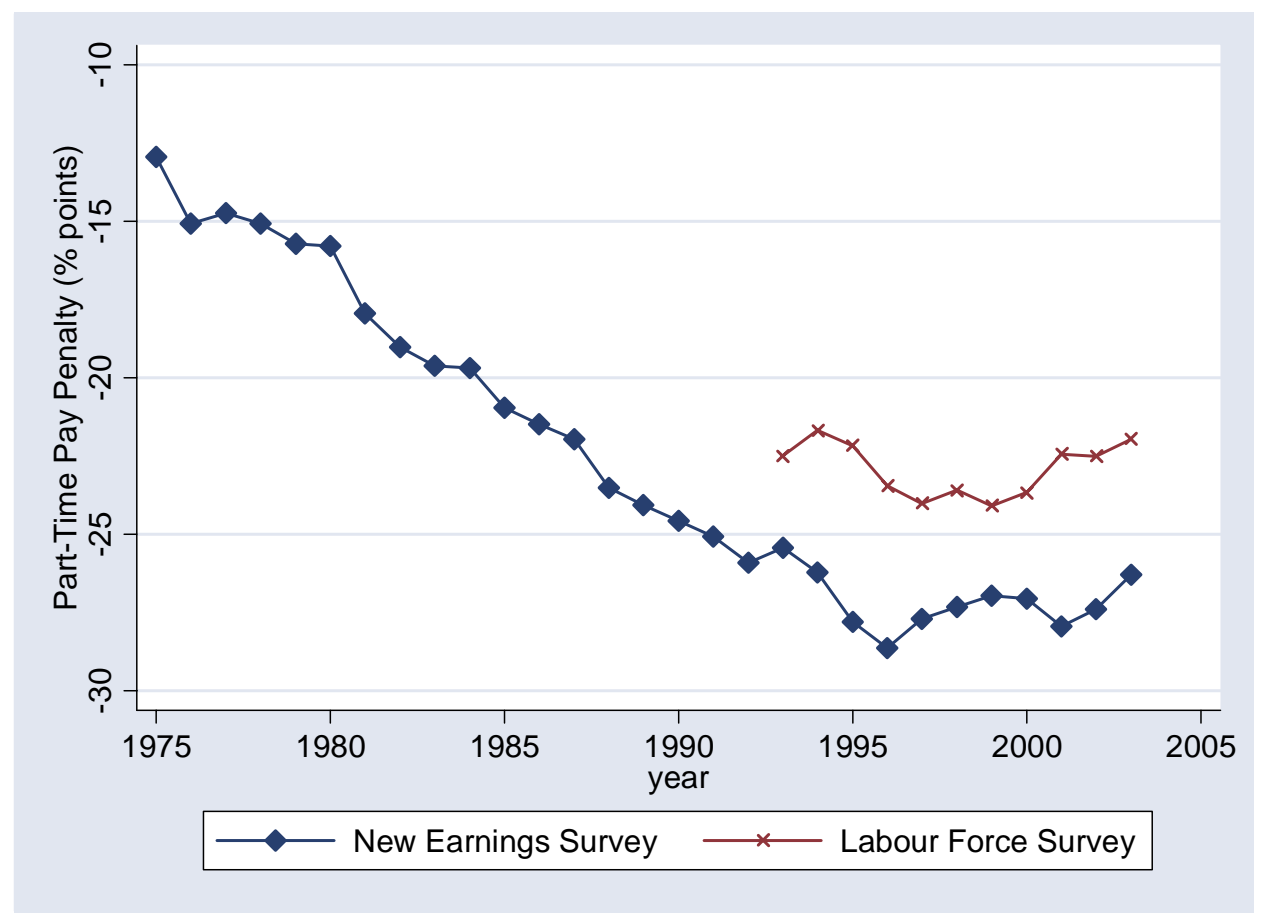

Note: The measure of pay used in hourly earnings. Definition of PT status for LFS is self-assessed and the sample excludes students. For NES the definition of PT status is basic usual hours $<=30$ with 25 -hour cut-off for teachers. 
Figure 2

The Evolution of the PT Pay Penalty, 1975-2001

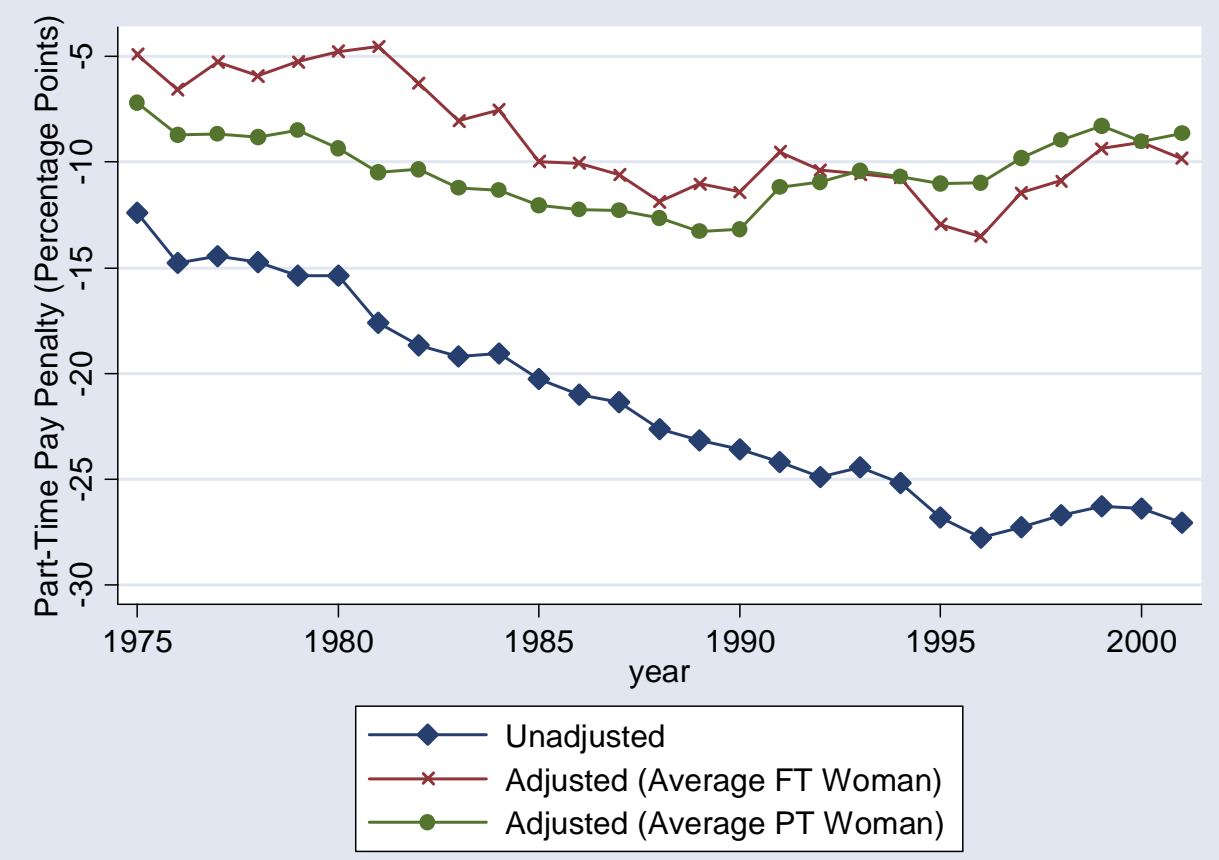

Notes: Controls are dummy variables for each age, 2-digit occupation and 2-digit industry. Separate regressions are estimated for each year. Source: New Earnings Survey.

Figure 3

The Relative Importance of Age, Industry and Occupation in Accounting for the PT Pay Penalty

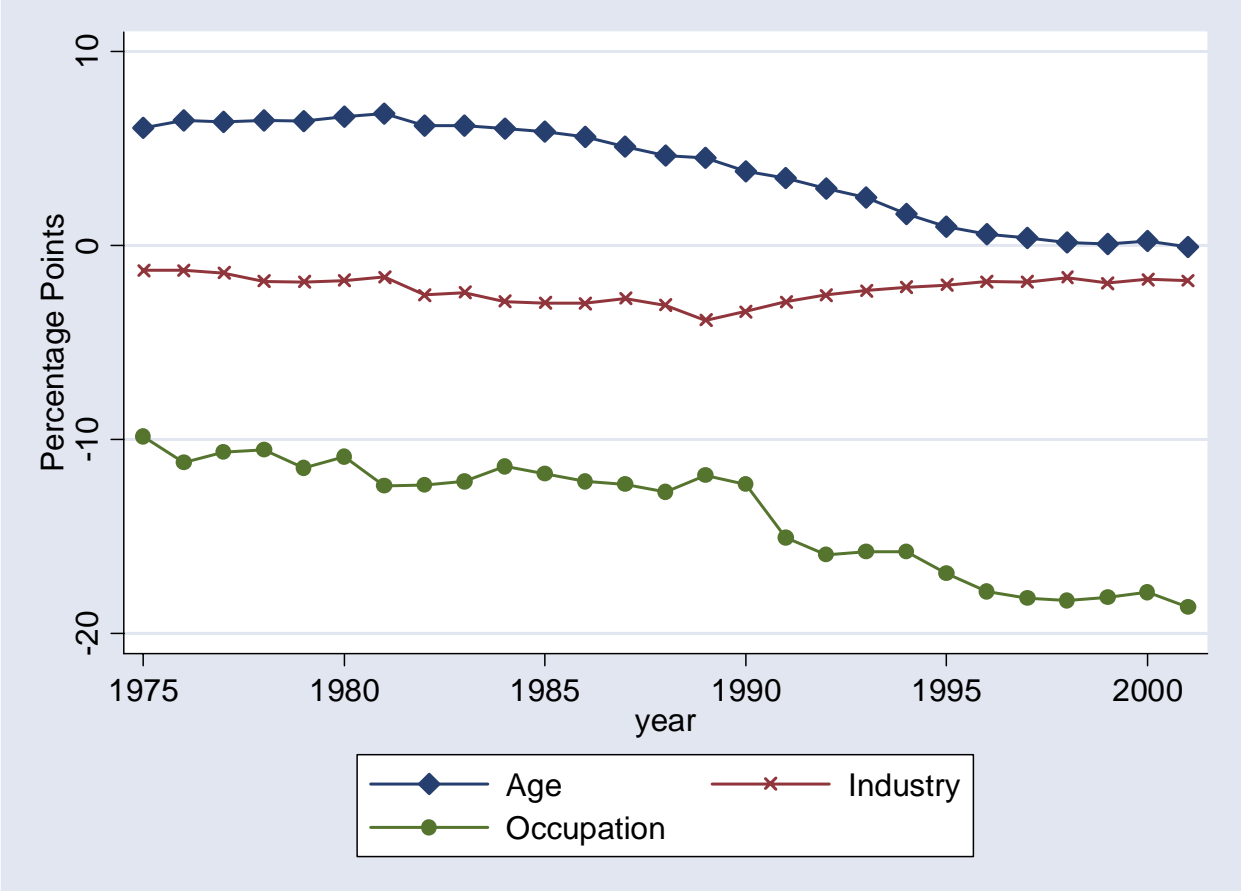

Note: Controls are dummy variables for each age, 2-digit occupation and 2-digit industry. Separate regressions are estimated for each year. Source: New Earnings Survey. 
Figure 4

The Role of Rising Wage Inequality

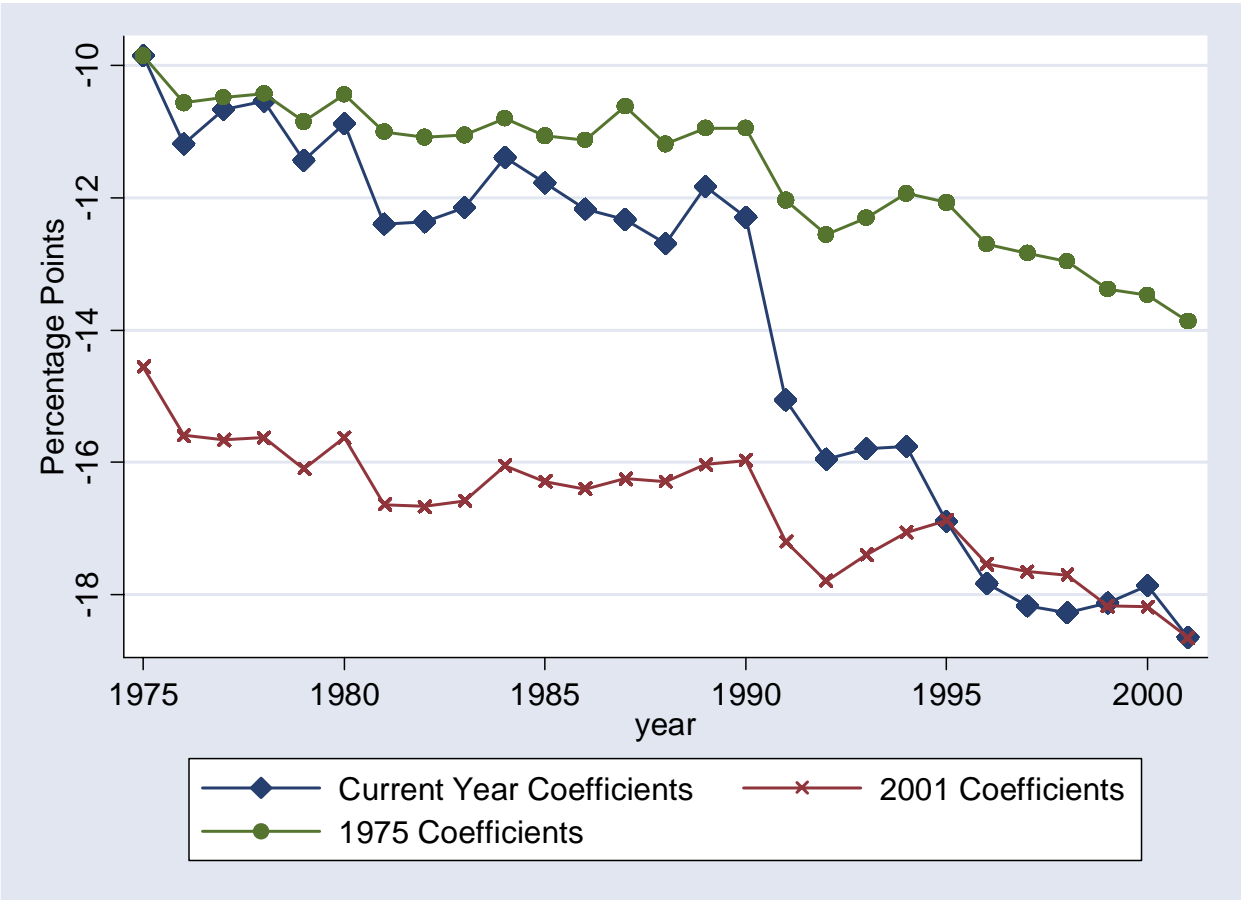

Note: Controls are dummy variables for each age, 2-digit occupation and 2-digit industry. Separate regressions are estimated for each year. The coefficients used are those estimated for full-time workers. Source: New Earnings Survey.

Figure 5

The Impact of the National Minimum Wage for FT and PT Women

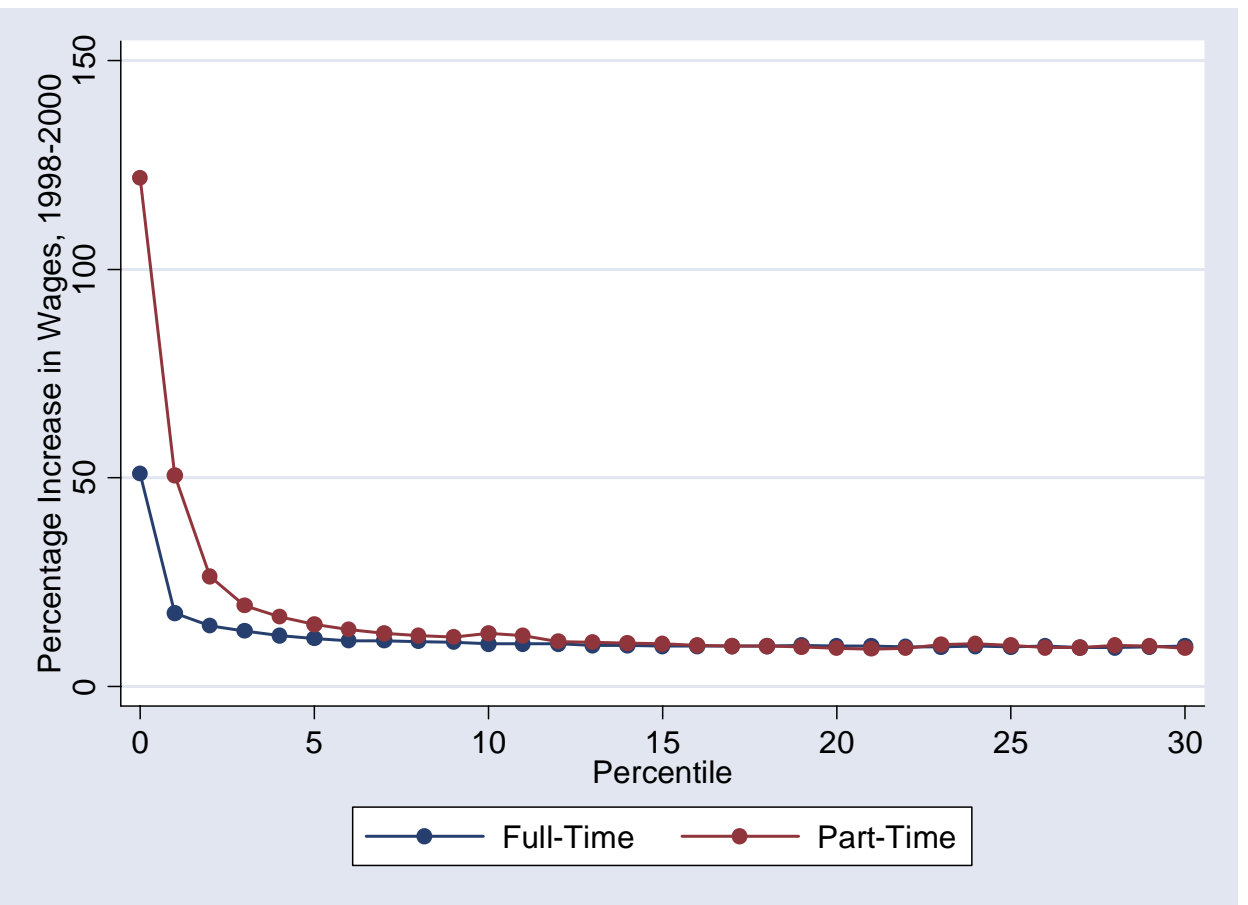

Base: Those aged 22-64 who are eligible for the adult minimum wage.

Note: Figure shows the percentage increase in earnings at each percentile of the FT and PT women's distribution of hourly wages. Source: New Earnings Survey, 1998 and 2000. 
Figure 6

Percentage of Workers with no Paid Holiday, 1992-2003

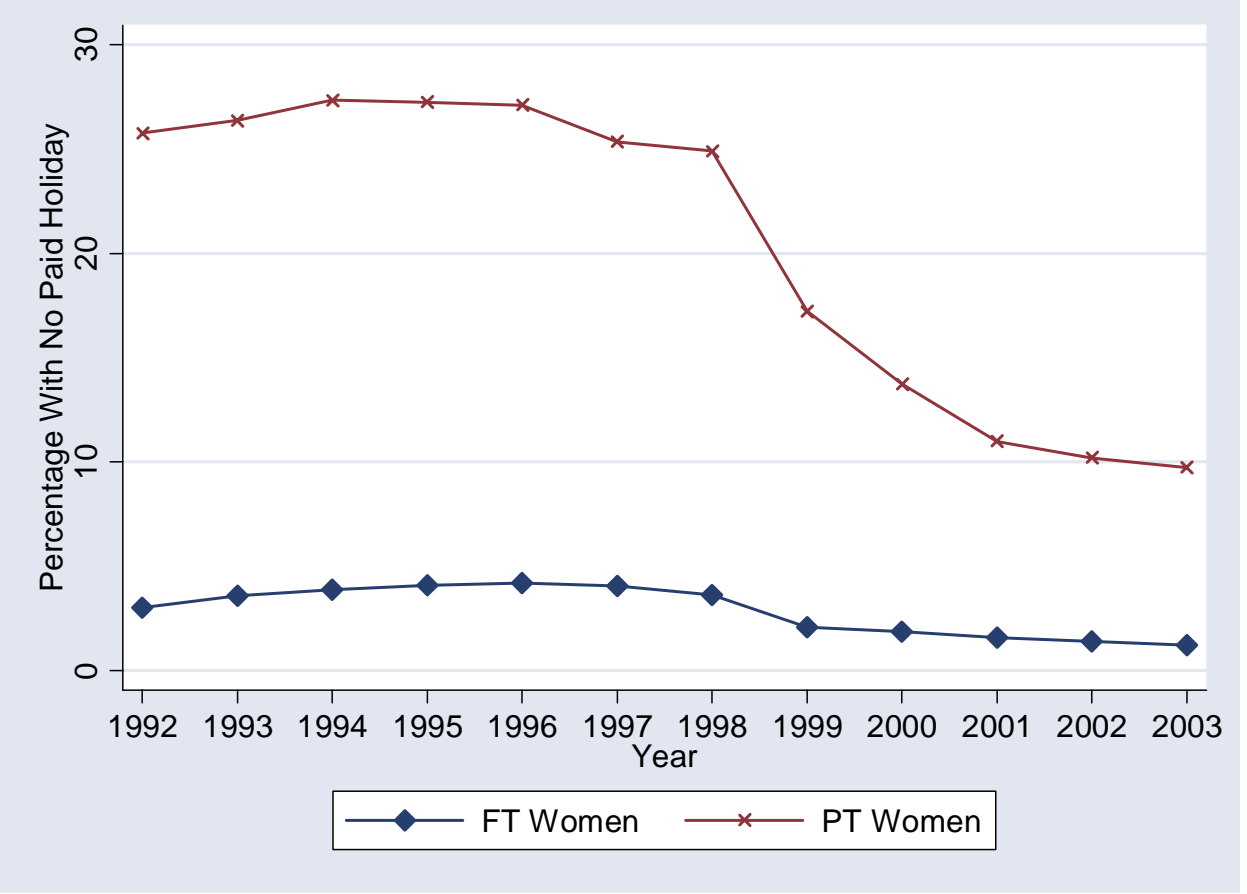

Base: Women aged 16-54 who are working and not in full-time education. Source: Labour Force Survey. 
Figure 7

Recent Changes in the Incidence of Flexible Working

a. $\quad$ Flex-Time and Term-Time Working

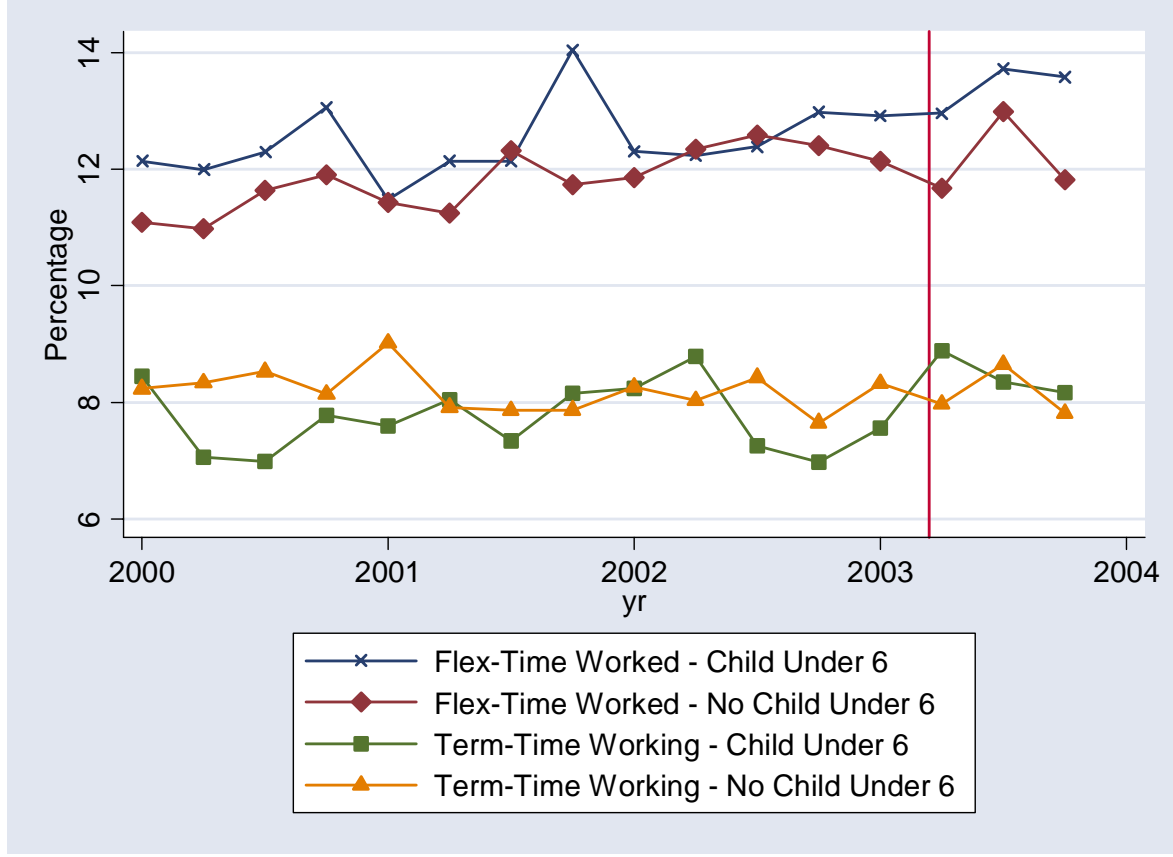

b. Job-Sharing and Annual Hours

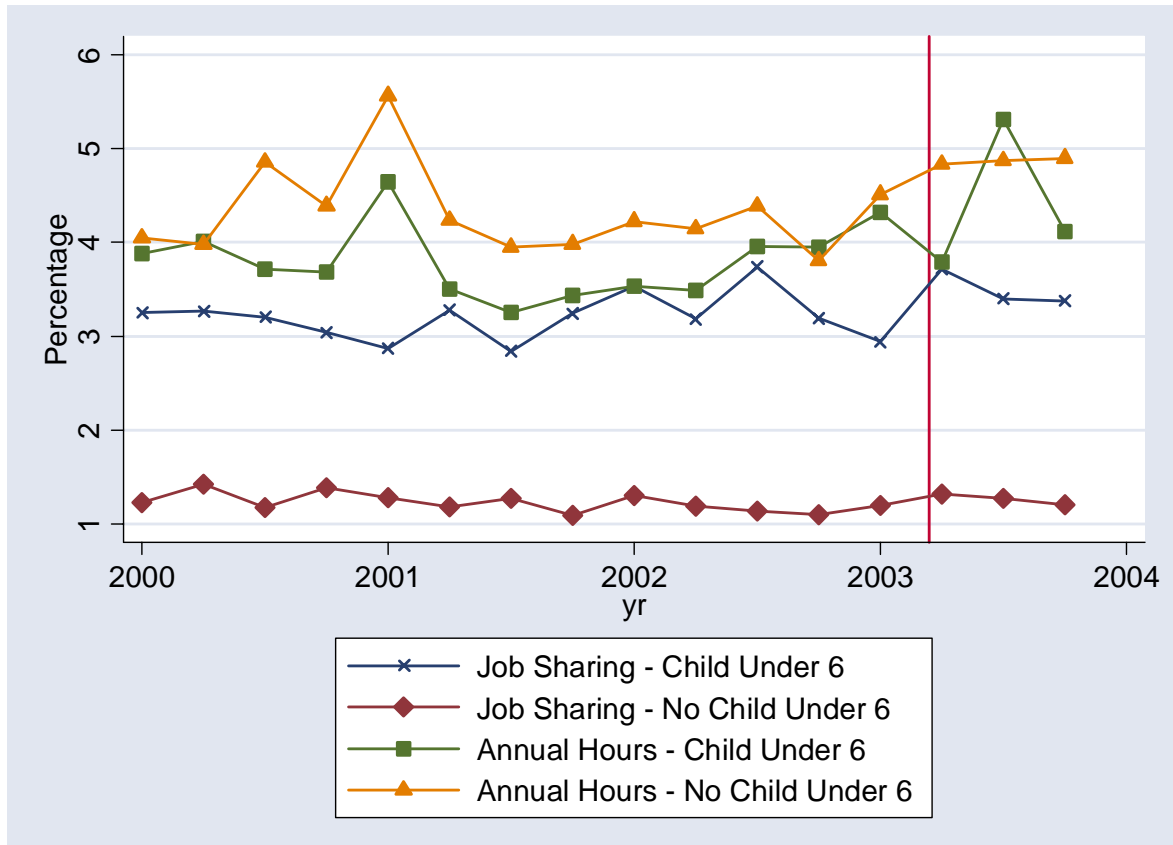

Note: The vertical line represents the introduction of the Right to Request Flexible Working in April 2003

Source: Labour Force Survey. 


\section{References}

Anderson, Tracy, John Forth, Hilary Metcalf and Simon Kirby (2001) “The Gender Pay Gap”, Report to the Women and Equality Unit, London.

Barzel, Yoram (1973) “The determination of daily hours and wages”, Quarterly Journal of Economics, 220-238.

Blackwell, Louisa (2001) "Occupational Sex Segregation and Part-time Work in Modern Britain”, Gender Work and Organization, 8, 146-163.

Blank, Rebecca (1990) “Are Part-time Jobs Lousy Jobs?” in G.Burtless (ed) A future of lousy jobs?, Brookings Institution: Washington DC.

Blau, Francine and Lawrence Kahn (2003) "Understanding International Differences in the Gender Pay Gap”, Journal of Labor Economics, 21, 106-144.

Casey, Bernard, Hilary Metcalf and Neil Millward (1997) Employers’ Use of Flexible Labour, London: Policy Studies Institute.

Connolly, Sara and Mary Gregory (2006) “Moving Down? Women’s Part-Time Work and Occupational Change in Britain, 1991-2001”.

Department of Trade and Industry (2003) Flexible Working: The right to request and the duty to consider, PL520, http://www.dti.gov.uk/er/individual/flexwork-pl520.pdf.

Department of Trade and Industry (2004) "Right to Request Flexible Working: Review of Impact in first year of legislation”, report by Working Families to DTI, March 2004, https://www.workingfamilies.org.uk/asp/employer_zone/reports/R2R_Report_March2004.d oC.

Dickens, Richard and Alan Manning (2004) "Has The National Minimum Wage Reduced UK Wage Inequality?”, forthcoming Journal of the Royal Statistical Society Series C.

DiNardo John, Nicole, M. Fortin and Thomas Lemieux, (1996), “Labor Market Institutions and the Distribution of Wages 1973-1992: A Semiparametric Approach” Econometrica; 64(5), September, pages 1001-44.

Ermisch, John F. and Robert E. Wright (1993) "Wage offers and Full-time and Part-time Employment by British Women”, Journal of Human Resources, 28, 111-133.

Harkness, Susan (2002) Women and Work: Changes in Employment and Earnings since the 1970s: PhD Thesis, University College London.

Houston, Diane M. and Gillian Marks (2003) “The Role of Planning and Workplace Support in Returning to Work after Maternity Leave”, British Journal of Industrial Relations, 41, 197-214.

Jones, E.B. and J.E. Long (1979) "Part-Week Work and Human Capital Investment by Married Women”, Journal of Human Resources, 14, 563-578. 
Joshi, Heather and Andrew Hinde (1993) "Employment After Child-Bearing in Post-War Britain: Cohort-Study Evidence on contrasts within and across generations”, European Sociological Review, 9, 203-227.

Low Pay Commission (2003) “The National Minimum Wage: Fourth Report of the Low Pay Commission”, HMSO: London, http://www.lowpay.gov.uk/lowpay/lowpay-nmw.pdf .

Lundberg, Shelly (1985) “Tied Wage-Hours Offers and the Endogeneity of Wages”, Review of Economics and Statistics, 67, 405-410.

Machin, Stephen (2003) “Wage Inequality since 1975”, in Richard Dickens, Paul Gregg and Jonathan Wadsworth (eds.) The Labour Market Under New Labour: The State of Working Britain, Palgrave Macmillan: Hampshire.

Manning, Alan and Barbara Petrongolo (2004) The Part-Time Pay, Report for Women and Equality Unit, DTI

http://www.womenandequalityunit.gov.uk/research/part_time_paypenalty.pdf

Martin, Jean and Ceridwen Roberts (1984) Women and Employment: A Lifetime

Perspective, London H.M.S.O.

Moffitt, Robert (1984) “The Estimation of a Joint Wage-Hours Labor Supply Model”, Journal of Labor Economics, 2, 550-566.

Montgomery, Mark (1988) "On the Determinants of Employer Demand for Part-time Workers”, Review of Economics and Statistics, 112-117.

Palmer, Tom (2004) “Results of the first flexible working employee survey”, DTI Employment Relations Occasional Papers, http://www.dti.gov.uk/er/emar/flex_survey_results.pdf .

Robinson, Helen (2002) "Wrong side of the track. The impact of the minimum wage on gender pay gaps in Britain" Oxford Bulletin of Economics and Statistics, 64, 417-448.

Stevens, Jane, Juliet Brown and Caroline Lee (2004) "The Second Work-Life Balance Study: Results from the Employees' Survey”, DTI Employment Relations Research Series No. 27 http://www.dti.gov.uk/er/emar/errs27.pdf .

Woodland, Stephen, Nadine Simmonds, Marie Thornby, Rory Fitzgerald and Alice McGee (2003) “The Second Work-Life Balance Study: Results from the Employer Survey”, DTI Employment Relations Research Series No. 22, http://www.dti.gov.uk/er/emar/errs22MainReport.pdf . 